\title{
Tautomers and Acid Dissociation Constants of 6-Selenoguanine from Density Functional Theoretical Calculations
}

\author{
Yongseong Kim, Yun Hee Jang, ${ }^{\dagger}$ Hyun Cho, ${ }^{\dagger}$ and Sungu Hwang ${ }^{\S, *}$ \\ Department of Science Education, Kyungnam University, Masan 631-701, Korea \\ ${ }^{\dagger}$ Department of Materials Science and Engineering, Gwangju Institute of Science and Technology, Gwangju 500-712, Korea \\ ¿Department of Nanomechatronics Engineering, Pusan National University, Miryang 627-706, Korea \\ ${ }^{\S}$ Department of Nanomedical Engineering, Pusan National University, Miryang 627-706, Korea \\ *E-mail: sungu@pusan.ac.kr
}

Received July 16, 2010, Accepted August 17, 2010

Key Words: 6-Selenoguanine, Tautomeric equilibrium, Acid dissociation constants, Density functional theory, Poisson-Boltzmann continuum-solvation model

A number of analogues of nucleic acid bases have been the target of extensive studies because of their importance in many biological studies. The oxygen of both purine and pyrimidine bases is substituted with sulfur or selenium to produce an important class of analogues. 6 -Selenoguanine (SeG) has a significant activity against L5178Y lymphoma cells. ${ }^{1}$ However, the detailed mechanism of the antiplastic action is not known yet. Information on the acid dissociation constants and the tautomerism of the molecules is required to provide a molecular level understanding of biological processes. Proton-transfer in the nucleic acid pairs and the presence of the tautomeric equilibrium play an important role in the mispair formation during the DNA replication. ${ }^{2}$

A protocol based on a density functional theory (DFT) quantum mechanics method was developed in order to understand the keto-enol and amino-imino tautomeric equilibrium of normal and damaged DNA bases in various environments and to calculate their $\mathrm{p} K_{\mathrm{a}}$ values in water. ${ }^{2-4}$ This scheme was applied to methylated purine nucleobases, and the macroscopic and microscopic $\mathrm{p} K_{\mathrm{a}}$ values were successfully reproduced. ${ }^{5,6}$ In this study, the same method was used to calculate the relative tautomeric stabilities and the $\mathrm{p} K_{\mathrm{a}}$ values of $\mathrm{SeG}$ compared to the experimental $\mathrm{p} K_{\mathrm{a}}$ values.

The tautomers of neutral SeG that were considered in this study are shown in Scheme 1, and their relative free energies and relative populations in equilibrium in the gas and aqueous phases are given in Table 1. In the gas phase, 6 -seleno tautomer $\mathbf{2}$ was the most stable, and tautomer $\mathbf{1}$ was second with a Gibbs energy difference of $3.4 \mathrm{kcal} / \mathrm{mol}$. The third most stable tautomer was selenolic form 7 with proton on N9. The energy difference between the seleno- and selenolic-forms was rather large in the gas phase. These computational results agreed with
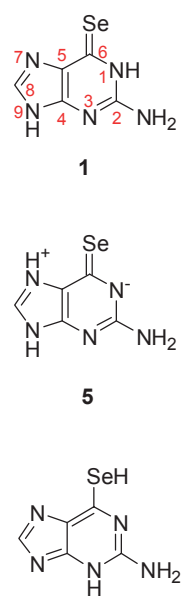<smiles>Nc1nc2nc[nH]c2c(=[Se])[nH]1</smiles>
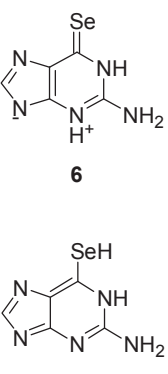

10<smiles>Nc1nc(=[Se])c2nc[nH]c2[nH]1</smiles>

3
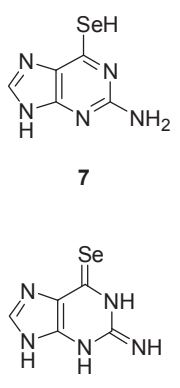

11

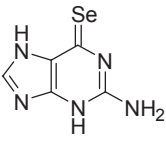

4

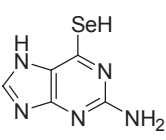

8

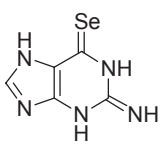

12
Scheme 1. Tautomers of neutral $\mathrm{SeG}$

Table 1. Relative free energies $(\mathrm{kcal} / \mathrm{mol})$ of the tautomers of neutral 6-selenoguanine and their relative Boltzmann populations in equilibrium: (a) Gas phase and (b) aqueous phase

\begin{tabular}{ccccccccccccc}
\hline name & $\mathbf{1}$ & $\mathbf{2}$ & $\mathbf{3}$ & $\mathbf{4}$ & $\mathbf{5}$ & $\mathbf{6}$ & $\mathbf{7}$ & $\mathbf{8}$ & $\mathbf{9}$ & $\mathbf{1 0}$ & $\mathbf{1 1}$ & $\mathbf{1 2}$ \\
\hline type & $\begin{array}{c}\text { Amino- } \\
\text { seleno }\end{array}$ & $\begin{array}{c}\text { Amino- } \\
\text { seleno }\end{array}$ & $\begin{array}{c}\text { Amino- } \\
\text { seleno }\end{array}$ & $\begin{array}{c}\text { Amino- } \\
\text { seleno }\end{array}$ & $\begin{array}{c}\text { Amino- } \\
\text { seleno }\end{array}$ & $\begin{array}{c}\text { Amino- } \\
\text { seleno }\end{array}$ & $\begin{array}{c}\text { Amino- } \\
\text { selenolic }\end{array}$ & $\begin{array}{c}\text { Amino- } \\
\text { selenolic }\end{array}$ & $\begin{array}{c}\text { Amino- } \\
\text { selenolic }\end{array}$ & $\begin{array}{c}\text { Amino- } \\
\text { selenolic }\end{array}$ & $\begin{array}{c}\text { Imino- } \\
\text { seleno }\end{array}$ & $\begin{array}{c}\text { Imino- } \\
\text { seleno }\end{array}$ \\
\hline $\begin{array}{c}\text { (a) gas } \\
\Delta G_{g, r e l}^{0}{ }^{a}\end{array}$ & 3.4 & 0.0 & 23.7 & 7.5 & 16.4 & 26.3 & 4.6 & 9.7 & 17.2 & 24.3 & 18.4 & 7.7 \\
Population & $3 \times 10^{-3}$ & 1.0 & $4 \times 10^{-18}$ & $3 \times 10^{-6}$ & $9 \times 10^{-13}$ & $5 \times 10^{-20}$ & $1 \times 10^{-4}$ & $7 \times 10^{-8}$ & $2 \times 10^{-13}$ & $1 \times 10^{-18}$ & $3 \times 10^{-14}$ & $2 \times 10^{-6}$ \\
$\begin{array}{c}\text { (b) aqueous } \\
\Delta G_{\text {aq, rel }}^{0}\end{array}$ & 0.0 & 1.0 & 4.9 & 3.0 & 3.4 & 6.7 & 13.0 & 14.5 & 17.6 & 19.8 & 11.0 & 10.4 \\
Population & 0.84 & 0.16 & $2 \times 10^{-4}$ & $5 \times 10^{-3}$ & $3 \times 10^{-3}$ & $1 \times 10^{-5}$ & $2 \times 10^{-10}$ & $2 \times 10^{-11}$ & $1 \times 10^{-13}$ & $2 \times 10^{-15}$ & $6 \times 10^{-9}$ & $2 \times 10^{-8}$ \\
\hline
\end{tabular}

${ }^{a}$ Relative free energies with respect to $\Delta G_{g}^{0}$ (2). ${ }^{b}$ Relative free energies with respect to $\Delta G_{a q}^{0}(\mathbf{1})$. 
Table 2. Relative free energies $(\mathrm{kcal} / \mathrm{mol})$ of the tautomers of anionic 6 -selenoguanine and their relative Boltzmann populations in equilibrium: (a) Gas phase and (b) aqueous phase

\begin{tabular}{cccccc}
\hline name & $\mathbf{1 3}^{-}$ & $\mathbf{1 4}^{-}$ & $\mathbf{1 5}$ & $\mathbf{1 6}$ & $\mathbf{1 7}$ \\
\hline type & $\begin{array}{c}\text { Amino- } \\
\text { seleno }\end{array}$ & $\begin{array}{c}\text { Amino- } \\
\text { seleno }\end{array}$ & $\begin{array}{c}\text { Amino- } \\
\text { seleno }\end{array}$ & $\begin{array}{c}\text { Amino- } \\
\text { seleno }\end{array}$ & $\begin{array}{c}\text { Amino- } \\
\text { selenolic }\end{array}$ \\
\hline $\begin{array}{c}\text { (a) gas } \\
\Delta G_{g, \text { rel }}^{0}{ }^{a}\end{array}$ & 7.6 & 0.0 & 5.1 & 14.8 & 10.7 \\
Population & $3 \times 10^{-3}$ & 1.0 & $2 \times 10^{-4}$ & $1 \times 10^{-11}$ & $1 \times 10^{-8}$ \\
$\begin{array}{c}\text { (b) aqueous } \\
\Delta G_{\text {aq, rel }}^{0}\end{array}$ & 0.0 & 0.6 & 1.7 & 4.1 & 15.6 \\
Population & 0.71 & 0.25 & 0.04 & $8 \times 10^{-4}$ & $3 \times 10^{-12}$ \\
\hline
\end{tabular}

${ }^{a}$ Relative free energies with respect to $\Delta G_{g}^{0}\left(\mathbf{1 4}^{-}\right) .{ }^{b}$ Relative free energies with respect to $\Delta G_{a q}^{0}\left(\mathbf{1 3}^{-}\right)$.

the previous theoretical results. ${ }^{7}$ For guanine, the Gibbs energy difference between the keto- and enol-forms was around 1.0 $\mathrm{kcal} / \mathrm{mol}^{2}$

In the aqueous phase, the free energy of the tautomers increased in the following order: $\mathbf{1}(84 \%)<\mathbf{2}(16 \%)<\mathbf{4}<\mathbf{5}<\mathbf{3}$. The other forms were at least $5 \mathrm{kcal} / \mathrm{mol}$ higher than the most stable tautomer $\mathbf{1}$. The relative stability order was the same as guanine, ${ }^{2}$ and was in good agreement with the previous calculations for $\mathrm{SeG}^{7}$ As with guanine, ${ }^{2}$ tautomer 1 with a large dipole moment of $8.11 \mathrm{D}$ was more greatly stabilized by water than 2 with 2.21 D. The lower intramolecular repulsion between the $\mathrm{NH}_{2}$ protons and the neighboring protons on $\mathrm{N} 1$ or $\mathrm{N} 3$ was another source of the stability of the seleno-type tautomers. ${ }^{2}$

The tautomers of anionic $\left(\mathbf{1 3}^{-}-\mathbf{1 7}\right) \mathrm{SeG}$ that were considered in this study are shown in Scheme 2, and their relative free energies and relative populations in equilibrium in the gas and aqueous phases are given in Table 2 . The dianionic form $\left(\mathbf{1 8}^{2-}\right)$ is also shown in Scheme 2. Tautomer $14^{-}$was most stable in the gas phase, and tautomer $13^{-}$was most stable in the aqueous phase. Again, the stabilization of $\mathbf{1 3}^{-}$by water was caused by the large dipole moment of $\mathbf{1 3}^{-}$. In both phases, the contribution of the selenolic species $17^{-}$was negligible.

The tautomers of cationic $\left(\mathbf{1 9}^{+}-\mathbf{2 8}^{+}\right) \mathrm{SeG}$ that were considered in this study are shown in Scheme 3, and their relative free energies and relative populations in equilibrium in the gas and

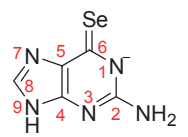

$13^{-}$<smiles></smiles>

$17^{-}$

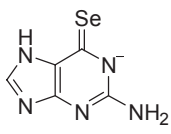<smiles>Nc1nc2nc[nH]c2c(=[Se])[nH]1</smiles>

$15^{-}$

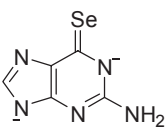

$18^{2-}$
Scheme 2. Tautomers of anionic and dianionic SeG

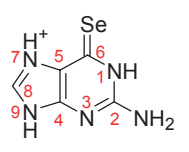

$19^{+}$<smiles>Nc1nc(S)c2[nH]cnc2[nH+]1</smiles>

$23^{+}$

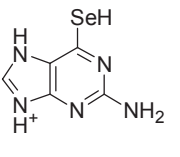

$27^{+}$<smiles>Nc1[nH]c(=[Se])c2[nH]cnc2[nH+]1</smiles>

$20^{+}$

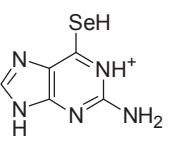

$24^{+}$<smiles></smiles>

$28^{+}$
Scheme 3. Tautomers of cationic $\mathrm{SeG}$

aqueous phases are given in Table 3 . Tautomer $\mathbf{1 9}^{+}$, which was protonated at N7, was most stable for both the gas and aqueous phases. Selenolic tautomers $\mathbf{2 3}^{+}-\mathbf{2 8}^{+}$had higher Gibbs energies than the seleno-forms in the gas phase, and the difference becomes much greater in the aqueous phase. As with guanine, ${ }^{2}$ the protonation did not shift the tautomeric equilibrium to the selenolic forms.

The macroscopic $\mathrm{p} K_{\mathrm{a}}$ values were calculated using Equation (3). The $\mathrm{p} K_{\mathrm{a} 1}$ value of $\mathrm{SeG}$ was 2.19 , the $\mathrm{p} K_{\mathrm{a} 2}$ value was 7.77, and the $\mathrm{p} K_{\mathrm{a} 3}$ value was 11.35 . The $\mathrm{p} K_{\mathrm{a} 2}$ of $\mathrm{SeG}$ was in good

Table 3. Relative free energies $(\mathrm{kcal} / \mathrm{mol})$ of the tautomers of cationic 6-selenoguanine and their relative Boltzmann populations in equilibrium: (a) Gas phase and (b) aqueous phase

\begin{tabular}{ccccccccccc}
\hline name & $\mathbf{1 9}^{+}$ & $\mathbf{2 0}^{+}$ & $\mathbf{2 1}^{+}$ & $\mathbf{2 2}^{+}$ & $\mathbf{2 3}^{+}$ & $\mathbf{2 4}^{+}$ & $\mathbf{2 5}^{+}$ & $\mathbf{2 6}^{+}$ & $\mathbf{2 7}^{+}$ & $\mathbf{2 8}^{+}$ \\
\hline type & $\begin{array}{c}\text { Amino- } \\
\text { seleno }\end{array}$ & $\begin{array}{c}\text { Amino- } \\
\text { seleno }\end{array}$ & $\begin{array}{c}\text { Amino- } \\
\text { seleno }\end{array}$ & $\begin{array}{c}\text { Amino- } \\
\text { seleno }\end{array}$ & $\begin{array}{c}\text { Amino- } \\
\text { selenolic }\end{array}$ & $\begin{array}{c}\text { Amino- } \\
\text { selenolic }\end{array}$ & $\begin{array}{c}\text { Amino- } \\
\text { selenolic }\end{array}$ & $\begin{array}{c}\text { Amino- } \\
\text { selenolic }\end{array}$ & $\begin{array}{c}\text { Amino- } \\
\text { selenolic }\end{array}$ & $\begin{array}{c}\text { Amino- } \\
\text { selenolic }\end{array}$ \\
\hline $\begin{array}{c}\text { (a) gas } \\
\Delta G_{g, \text { rel }}^{0}{ }^{0}\end{array}$ & 0.0 & 6.2 & 19.4 & 19.5 & 6.1 & 6.4 & 14.5 & 11.5 & 8.2 & 31.0 \\
Population & 1.0 & $3 \times 10^{-5}$ & $6 \times 10^{-15}$ & $5 \times 10^{-15}$ & $3 \times 10^{-5}$ & $2 \times 10^{-5}$ & $3 \times 10^{-11}$ & $1 \times 10^{-9}$ & $1 \times 10^{-6}$ & $2 \times 10^{-23}$ \\
$\begin{array}{c}\text { (b) aqueous } \\
\Delta G_{\text {aq, rel }}^{0}\end{array}$ & 0.0 & 2.4 & 3.2 & 4.8 & 13.3 & 12.9 & 15.3 & 13.8 & 13.0 & 21.0 \\
Population & 0.98 & 0.02 & $5 \times 10^{-3}$ & $3 \times 10^{-4}$ & $2 \times 10^{-10}$ & $4 \times 10^{-10}$ & $6 \times 10^{-12}$ & $7 \times 10^{-11}$ & $3 \times 10^{-10}$ & $4 \times 10^{-16}$ \\
\hline
\end{tabular}

${ }^{a}$ Relative free energies with respect to $\Delta G_{g}^{0}\left(\mathbf{1 9}^{+}\right) .{ }^{b}$ Relative free energies with respect to $\Delta G_{a q}^{0}\left(\mathbf{1 9}^{+}\right)$. 


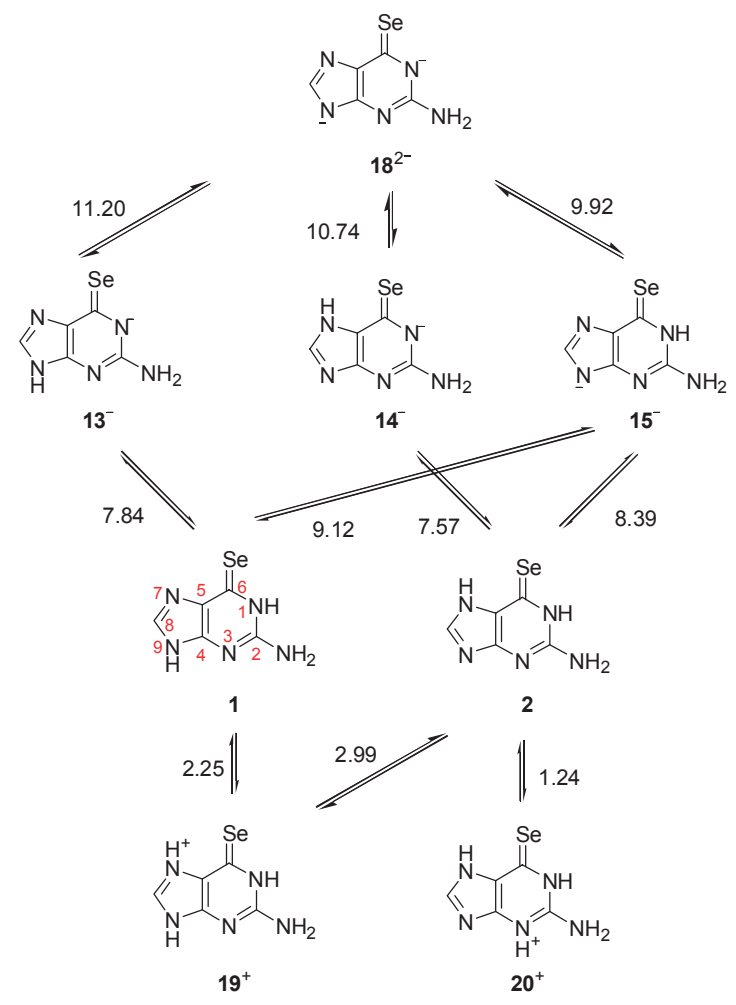

Figure 1. Calculated micro $\mathrm{p} K_{\mathrm{a}}$ values of 6-selenoguanine.

agreement with the experimental value of $7.6 \pm 0.1^{8}$ (spectrophotometric measurements) and $7.8 \pm 0.1^{9}$ (potentiometric titration). The $\mathrm{p} K_{\mathrm{a} 2}$ value of $\mathrm{SeG}$ was smaller than guanine ( $\mathrm{p} K_{\mathrm{a} 2}=$ 9.4), as was the case in the analogous compounds, pyridone, ${ }^{10}$ hypoxanthine, ${ }^{11}$ and uracil $^{11}$ when $\mathrm{O}$ was substituted with Se. The increased acidity was believed to be due to the stabilization of the deprotonated anionic forms when Se replaced O. ${ }^{10}$

The microscopic $\mathrm{p} K_{\mathrm{a}}$ values are shown in Figure 1. These microscopic $\mathrm{p} K_{\mathrm{a}}$ values provided clues toward a better understanding of the chemistry of the nucleobases, such as their reactivity with enzymes, their metal ion-binding properties and their proton transfer. For example, the microscopic $\mathrm{p} K_{\mathrm{a}}$ value corresponding to the deprotonation from 1 to $\mathbf{1 3}^{-}$(deprotonation of N1 proton) was 7.84, which suggested that SeG more easily transferred protons to cytosine than guanine (The corresponding micro $\mathrm{p} K_{\mathrm{a}}$ value was 9.65 for guanine. See reference 2 ).

In summary, the relative stabilities of the tautomers of $\mathrm{SeG}$ were calculated. In the aqueous phase, amino-seleno form 1 was the major tautomer of neutral $\mathrm{SeG}$ with a minor contribution from the other amino-seleno form 2 . The presence of the selenolic form was negligible from the calculations. The microscopic and macroscopic $\mathrm{p} K_{\mathrm{a}}$ values in the aqueous phase were calculated from this scheme. The calculated $\mathrm{p} K_{\mathrm{a}}$ value was in good agreement with the experimental data. These results demonstrated that this method could predict and explain the acid-base properties of SeG and could be used to understand the behavior of the species.

\section{Computational Details}

The site-specific microscopic $\mathrm{p} K_{\mathrm{a}}$ value is related to the Gibbs energy of the deprotonation process., ${ }^{2,3}$ For the deprotonation of the $i$-th tautomer of an acid HA into the $j$-th tautomer of the conjugate base $\mathrm{A}^{-}$, the Gibbs energy of the deprotonation reaction was calculated using the following equation:

$$
\Delta G_{\mathrm{deprot}, a q}^{0, i j}=\Delta G_{a q}^{0}\left(\mathrm{~A}_{j}^{-}\right)+\Delta G_{a q}^{0}\left(\mathrm{H}^{+}\right)-\Delta G_{a q}^{0}\left(\mathrm{HA}_{i}\right)
$$

The corresponding micro $\mathrm{p} K_{\mathrm{a}}^{i j}$ values is given by

$$
\mathrm{p} K_{\mathrm{a}}^{i j}=\Delta G_{\mathrm{deprot}, a q}^{0, i j} / 2.303 R T,
$$

where $R$ is the gas constant and $T$ is $298.15 \mathrm{~K}$. This micro $\mathrm{p} K_{\mathrm{a}}^{i j}$ value, the partial population of the $i$-th tautomer of the acid species $\left(f_{i}\right)$, and the partial population of the $j$-th tautomer of the conjugate base species $\left(f_{j}^{\prime}\right)$ were used to measure the macro $\mathrm{p} K_{\mathrm{a}}$ value.

$$
\mathrm{p} K_{\mathrm{a}}=\mathrm{p} K_{\mathrm{a}}^{i j}-\log f_{i}+\log f_{j}^{\prime}
$$

The standard Gibbs energy of each species ( $\mathrm{HA}, \mathrm{A}^{-}$, and $\mathrm{H}^{+}$) in water, $\Delta G_{a q}^{0}$, can be written as the sum of the gas-phase standard Gibbs energy $\Delta G_{g}^{0}$ and the standard Gibbs energy of solvation in water $\Delta G_{\text {solv }}^{0}$ :

$$
\Delta G_{a q}^{0}=\Delta G_{g}^{0}+\Delta G_{s o l v}^{0} .
$$

The standard Gibbs energy of each species in the gas phase, $\Delta G_{g}^{0}$, was obtained using the following equation:

$$
\Delta G_{g}^{0}=E_{0 \mathrm{~K}}+\mathrm{ZPE}+\Delta \Delta G_{0 \rightarrow 298 \mathrm{~K}} .
$$

The total energy of the molecule at $0 \mathrm{~K}\left(E_{0 \mathrm{~K}}\right)$ was calculated at the optimal geometry from the quantum mechanics (QM). The zero-point energy (ZPE) and the Gibbs energy change from 0 to $298 \mathrm{~K}\left(\Delta \Delta G_{0 \rightarrow 298 \mathrm{~K}}\right)$ were calculated from the vibrational frequencies that were obtained using QM. The translational and rotational contributions were also calculated according to the ideal gas approximation. The expression $\Delta G_{g}^{0}\left(\mathrm{H}^{+}\right)=2.5 R T^{-}$ $T \Delta \mathrm{S}_{0}=1.48-7.76=-6.28 \mathrm{kcal} / \mathrm{mol}$ was obtained from the previous literature. ${ }^{12}$ All of the QM calculations used the Jaguar v5.5 quantum chemistry software. ${ }^{13}$ The B3LYP/LACVP** level was used to optimize the geometry and calculate the vibrational frequencies. Then the LACVP $++* *$ basis set was used for the final geometry optimization based on the LACVP** geometry.

The continuum solvent model ${ }^{14,15}$ was applied to the calculations of the solvation energy. The solvation energy was given as the sum of the two terms. The electrostatic part of the solvation energy was evaluated using a self-consistent formalism with a numerical solution from the Poisson-Boltzmann (PB) equation. ${ }^{16}$ The non-electrostatic contribution was taken into account using a term that was proportional to the solvent-accessible surface (SAS) area of the solute. The atomic radii that were used to build this vdW envelope for the solute were taken from a previous work on guanine: $1.88 \AA$ for the $\mathrm{sp}^{2}$-hybridized 
carbon, $1.41 \AA$ for the nitrogen, $1.175 \AA$ for the hydrogen that was attached to the $\mathrm{sp}^{2}$-hybridized carbon, and $1.08 \AA$ for the other types of hydrogen. ${ }^{2}$ A value of $2.103 \AA$ was used for selenium from the UFF forcefield ${ }^{17}$ as implemented in Jaguar. All of the solvation energy calculations were carried out at the $\mathrm{B} 3 \mathrm{LYP} / \mathrm{LACVP}++* *$ level, and the geometry was re-optimized in solution. The solvation energy of a proton in water $\left(\Delta G_{s o l v}^{0}\right.$ $\left.\left(\mathrm{H}^{+}\right)\right)$was set at $-263.47 \mathrm{kcal} / \mathrm{mol}$, which resulted in a value of $-269.75 \mathrm{kcal} / \mathrm{mol}$ for standard Gibbs energy of a proton in water $\Delta G_{a q}^{0}\left(\mathrm{H}^{+}\right)$to be from previous studies. ${ }^{2-4}$

In summary, the following scheme was used to calculate the solution phase Gibbs energy of a chemical species:

$$
\begin{aligned}
\Delta G_{\mathrm{aq}}^{0}= & E_{0 \mathrm{~K}, \mathrm{~g}}^{\text {LACVP }++* *^{* *}}+\mathrm{ZPE}^{\mathrm{LACVP}^{* *}} \\
& +\Delta \Delta G_{0 \rightarrow 298 \mathrm{~K}}^{\text {LACVP** }^{*}}+\Delta G_{\text {solv }}^{0{ }^{\text {LACVP }++* *}} .
\end{aligned}
$$

Acknowledgments. This work was supported by the Program for Integrated Molecular systems (PIMS) of GIST.

\section{References}

1. Mautner, H. G.; Chu, S.-H.; Jaffe, J. J.; Sartorelli, A. C. J. Med. Chem. 1963, 6, 36 .
2. Jang, Y. H.; Goddard, W. A., III.; Noyes, K. T.; Sowers, L. C.; Hwang, S.; Chung, D. S. J. Phys. Chem. B 2003, 107, 344.

3. Jang, Y. H.; Goddard, W. A., III.; Noyes, K. T.; Sowers, L. C.; Hwang, S.; Chung, D. S. Chem. Res. Toxicol. 2002, 15, 1023.

4. Rogstad, K. N.; Jang, Y. H.; Sowers, L. C.; Goddard, W. A., III. Chem. Res. Toxicol. 2003, 16, 1455.

5. Hwang, S.; Jang, Y. H.; Cho, H.; Kim, Y. Bull. Korean Chem. Soc. 2010, 31, 168 .

6. Jang, Y. H.; Hwang, S.; Chung, D. S. Chem. Lett. 2007, 36, 1496.

7. Venkateswarlu, D.; Leszczynski, J. J. Phys. Chem. A 1998, 102, 6161.

8. Ross, A. F. In vivo and in vitro Studies of the Guanine Analog, 6-Selenoguanine; Brown University, 1972.

9. Chu, S.-H. J. Med. Chem. 1971, 14, 254.

10. Mautner, H. G.; Chu, S.-H.; Lee, C. M. J. Org. Chem. 1962, 27 , 3671.

11. Mautner, H. G. J. Am. Chem. Soc. 1956, 78, 5292.

12. Topol, I. A.; Tawa, G. J.; Burt, S. K.; Rashin, A. A. J. Phys. Chem. A 1997, 101, 10075.

13. Schrödinger. Jaguar; 5.5 ed.; Schrodinger: Portland, OR, 19912003.

14. Marten, B.; Kim, K.; Cortis, C.; Friesner, R. A.; Murphy, R. B.; Ringnalda, M. N.; Sitkoff, D.; Honig, B. J. Phys. Chem. 1996, 100, 11775.

15. Tannor, D. J.; Marten, B.; Murphy, R.; Friesner, R. A.; Sitkoff, D.; Nicholls, A.; Ringnalda, M. N.; Goddard, W. A., III.; Honig, B. J. Am. Chem. Soc. 1994, 116, 11875.

16. Honig, B.; Nicholls, A. Science 1995, 268, 1144.

17. Rappé, A. K.; Casewit, C. J.; Colwell, K. S.; Goddard, W. A., III.; Skiff, W. M. J. Am. Chem. Soc. 1992, 114, 10024. 